\title{
EDUCORETAX
}

Volume 1 No. 1, Maret 2021

\section{PENAGIHAN PAJAK TERHADAP WAJIB PAJAK BADAN PERSEROAN TERBATAS DALAM PROSES PAILIT}

\author{
Christabella Deandra Florentia Warouw'; Irwan Aribowo \\ 1)dheandraflo@gmail.com, Politeknik Keuangan Negara STAN \\ 2)irwan_aribowo@pknstan.ac.id, Politeknik Keuangan Negara STAN
}

\begin{abstract}
Tax debt is the basis for collection actions that arise because of the laws that regulate and bind taxpayers. In the bankruptcy process that occurs in Limited Liability Company (PT) corporate taxpayers, the act of collecting tax debts has many challenges. The position of the tax payable in the bankruptcy process should have prior rights as the preferred creditor. The main problem that forms the basis of this research is the act of collecting taxes by the tax bailiff against the corporate taxpayer of PT Bankruptcy. The main issues will be analyzed using regulations and literature related to the bankruptcy process. The purpose of this study was to determine the process of billing corporate taxpayers of PT Bankruptcy in KPP Besar Satu Taxpayers, the obstacles that occur, and the position of the tax debt in the bankruptcy process. The methods used in the research are literature review, interviews, and case studies. In this study there are also suggestions that are expected to be implemented and have an impact on billing actions against corporate taxpayers who experience bankruptcy.
\end{abstract}

Keywords: Tax Payable, Limited Liability Company, Bankruptcy, Tax Collection.

\begin{abstract}
Abstrak
Utang pajak merupakan dasar tindakan penagihan yang timbul karena adanya undang-undang yang mengatur dan mengikat wajib pajak. Pada proses pailit yang terjadi pada wajib pajak badan Perseroan Terbatas (PT), tindakan penagihan terhadap utang pajak memiliki banyak tantangan. Posisi utang pajak dalam proses kepailitan seharusnya memiliki hak mendahulu sebagai kreditur preferen. Pokok permasalahan yang menjadi dasar penelitian ini adalah tindakan penagihan pajak yang dilakukan jurusita pajak terhadap wajib pajak badan PT pailit. Pokok permasalahan akan dianalisa menggunakan peraturan-peraturan dan literatur yang berkaitan dengan proses pailit. Tujuan penelitian ini adalah untuk mengetahui proses tindakan penagihan wajib pajak badan PT pailit di KPP Wajib Pajak Besar Satu, hambatan yang terjadi, dan posisi utang pajak dalam proses pailit. Metode yang dilakukan dalam penelitian adalah tinjauan pustaka, wawancara, dan studi kasus. Dalam penelitian ini terdapat pula saran-saran yang diharapkan dapat terlaksana dan memberikan dampak pada tindakan penagihan terhadap wajib pajak badan PT yang mengalami pailit.
\end{abstract}

Kata kunci: Utang Pajak, Perseroan Terbatas, Kepailitan, Penagihan Pajak.

\section{PENDAHULUAN}

Perseroan Terbatas (PT) dalam menjalankan kegiatan usaha tidak terlepas hak dan kewajiban dari hubungan dengan berbagai pihak berdasarkan hukum. Salah satu kewajiban yang timbul merupakan utang perseroan dengan pihak kreditur. Timbulnya utang perseroan dapat dibagi menjadi dua, yaitu utang yang timbul akibat perjanjian atau dari perikatan berdasarkan undang-undang. Berbeda dengan utang niaga yang berdasarkan akibat perjanjian, utang pajak merupakan utang yang timbul akibat ketentuan perundang-undangan (Soemitro,1990).

Penerbitan surat ketetapan atau surat ketetapan atau surat sejenisnya yang berisi kekurangan pembayaran pajak merupakan dasar utang pajak. Apabila utang pajak tidak dilunasi sampai melewati jatuh tempo, Direktorat Jenderal Pajak (DJP) berhak menjalankan tindakan penagihan. Tujuan tindakan penagihan aktif adalah untuk membuat penanggung pajak melunasi utang pajak dan biaya penagihan pajak.

DJP melakukan tindakan penagihan aktif dengan cara menegur atau memperingatkan, melaksanakan penagihan seketika dan sekaligus, memberitahukan Surat Paksa, mengusulkan 


\section{EDUCORETAX}

Volume 1 No. 1, Maret 2021

pencegahan, melaksanakan penyitaan, melaksanakan penyanderaan, melelang barang yang telah disita. Serangkaian tindakan penagihan utang pajak dilakukan oleh jurusita pajak berdasarkan prosedur yang ditetapkan dalam Undang Undang Penagihan Pajak dengan Surat Paksa (UU PPSP).

Perseroan yang tidak memenuhi kewajiban melakukan pembayaran sampai melewati batas waktu yang ditetapkan secara terus menerus dapat dianggap lalai dalam mengelola perusahaan. Menurut Asikin (2011), kelalaian PT dalam memenuhi pembayaran utang dapat terjadi karena adanya kesengajaan atau keterpaksaan. Adanya keadaan dimana PT tidak dapat memenuhi kewajiban melakukan pembayaran (insolvent), kreditur atau perseroan dapat mengajukan permohonan pailit (Susilowati,2011). Pengajuan permohonan pailit diajukan ke Pengadilan Niaga. Tujuan permohonan pailit adalah menyelesaikan pelunasan utang PT secara adil terhadap para kreditur PT.

Akibat hukum putusan pailit, perseroan sebagai debitur berada dalam kondisi tidak memiliki kewenangan untuk melakukan pengurusan aset perusahaan. Seluruh harta PT berstatus sita umum dibawah penguasaan kurator yang ditunjuk oleh Hakim Pengadilan Niaga (Suharyanto, 2013). Kurator yang ditunjuk memiliki tugas dan wewenang melakukan pengurusan dan pemberesan atas harta PT dibawah pengawasan hakim pengawas. Hasil penjualan aset PT oleh kurator digunakan untuk membayar seluruh utang debitur pailit (PT) secara proporsional dan sesuai dengan struktur kreditur (Irawan, 2007).

Berdasarkan Pasal 21 Undang-Undang Nomor 28 Tahun 2007 dengan perubahan terakhir Undang-Undang Nomor 16 Tahun 2009 tentang Ketentuan Umum dan Tata Cara Perpajakan (UU KUP) yang menyatakan bahwa negara memiliki hak mendahulu untuk utang pajak atas barang-barang milik penanggung pajak. Pada pelaksanaannya, proses kepailitan tidak lepas dengan hubungan hukum dengan berbagai pihak yang menjadi kreditur PT pailit. Setiap kreditur memiliki dasar hukum kuat untuk didahulukan (lex specialis) dalam proses pailit. Peraturan dalam proses kepailitan belum jelas mengatur posisi kreditur dalam proses pailit.

Berdasarkan adanya perbedaan peraturan perpajakan dan pengaplikasian hak mendahulu utang pajak, penulis melakukan penelitian mengenai posisi utang pajak dalam proses pailit. Penelitian dilakukan karena hak mendahulu dalam UU KUP seharusnya memberikan peranan penting dalam tindakan penagihan utang pajak dalam proses pailit. Namun pada pelaksaanaan, utang pajak belum dapat didahulukan pelunasannya dalam proses pailit.

Penelitian dilakukan terhadap tindakan penagihan wajib pajak badan PT dalam proses pailit di KPP Wajib Pajak Besar Satu. KPP Wajib Pajak Besar Satu merupakan KPP satusatunya di Indonesia yang melaksanakan administrasi dan pengawasan wajib pajak besar pilihan dari sektor pertambangan dan jasa penunjang pertambangan, perbankan, dan jasa keuangan. Mayoritas wajib pajak terdaftar merupakan wajib pajak besar badan dalam bentuk PT. Wajib pajak badan pilihan tidak menjamin pelaksanaan pembayaran pajak berjalan lancar. Berdasarkan data yang didapat dari KPP Wajib Pajak Besar Satu, terdapat tindakan penagihan terhadap wajib pajak badan PT dalam proses pailit selama 5 (lima) tahun terakhir. Utang pajak yang menjadi dasar penagihan rata-rata memiliki nominal yang cukup besar.

Tindakan penagihan KPP Wajib Pajak Besar Satu dilakukan sesuai dengan prosedur yang diatur dalam UU PPSP. Berdasarkan penuturan jurusita pajak KPP Wajib Pajak Besar Satu, pelaksanaan tindakan penagihan pajak yang dilakukan juga mengalami hambatanhambatan yang terjadi. Guna menghadapi hambatan yang terjadi jurusita melakukan strategi untuk mengamankan penerimaan negara dengan tetap berdasarkan hukum yang berlaku.

Penelitian terdahulu yang sampai saat ini ditemukan penulis merupakan penelitian dengan metode tinjauan yuridis dan studi kasus. Penelitian tinjauan yuridis mengenai hak 


\section{EDUCORETAX}

Volume 1 No. 1, Maret 2021

mendahulu dalam penagihan utang pajak pada kasus kepailitan (Fernandez, 2012). Sedangkan penelitian studi kasus mengenai tindakan penagihan utang pajak yang terhenti dengan penolakan permohonan kasasi yang diajukan Kantor Pelayanan Pajak oleh Mahkamah Agung (Teguh, 2016). Sampai saat ini, tidak banyak penelitian perihal proses tindakan penagihan pajak atas Wajib Pajak dari awal penagihan hingga selesai proses pailit.

Tujuan penelitian adalah mengetahui proses tindakan penagihan terhadap wajib pajak pailit, posisi utang pajak dalam proses pailit, kendala tindakan penagihan terhadap wajib pajak PT pailit, dan solusi mengatasi kendala tindakan penagihan terhadap wajib pajak PT pailit.

\section{LANDASAN TEORI}

\section{Perseroan Terbatas}

Perseroan Terbatas berasal dari dua kata yaitu perseroan yang berarti modal yang terbagi atas sero-sero dan kata terbatas yang berarti tanggung jawab pemegang saham sebatas nilai nominal atas saham yang dimiliki (Khairandy, 2009). Pengertian PT dalam undang-undang tertuang pada Pasal 1 ayat (2) Undang-Undang No.40 Tahun 2007 tentang Perseroan Terbatas (UU PT) yang memberikan pengertian:

"Perseroan Terbatas adalah badan hukum yang merupakan persekutuan modal, didirikan berdasarkan perjanjian melakukan kegiatan usaha dengan modal yang seluruhnya terbagi dalam saham dan memenuhi persyaratan yang ditetapkan undangundang dan peraturan pelaksanaannya"

PT dapat dikatakan sebagai badan hukum tidak sebatas memenuhi persyaratan dalam UU PT, namun juga harus memenuhi persyaratan formil yaitu mendapat pengesahan dari Menteri Hukum dan HAM. Dampak sifat PT sebagai badan hukum adalah terdapat hak mendahului dari kreditur badan hukum atas harta kekayaan badan hukum pada saat pembubaran badan hukum. Hal ini menunjukan bahwa harta kekayaan badan hukum tersebut tidak diambil secara sembarangan oleh pendiri perseroan dan/atau pemegang saham.

\section{Utang Pajak}

Pajak dari sudut hukum merupakan suatu perikatan yang timbul berdasarkan peraturan perundang-undangan. Perikatan tersebut menyebabkan timbulnya kewajiban warga negara membayarkan bagian dari penghasilannya berdasarkan perhitungan tertentu kepada negara. Atas kewajiban tersebut, negara memiliki hak untuk memaksa wajib pajak memenuhi kewajibannya. Pajak yang telah dibayarkan digunakan untuk penyelenggaraan pemerintah. Pajak yang dipungut sudah seharusnya berdasarkan undang-undang sehingga menjamin adanya kepastian hukum bagi fiskus maupun wajib pajak (Soemitro, 2004).

Berdasarkan Pasal 1 angka 8 Undang-Undang Nomor 19 Tahun 2000 tentang Penagihan Pajak dengan Surat Paksa, utang pajak adalah pajak yang masih harus dibayar termasuk sanksi administrasi berupa bunga, denda, atau kenaikan yang tercantum dalam surat ketetapan pajak atau surat sejenisnya berdasarkan peraturan perundang-undangan perpajakan. Jangka waktu pemenuhan kewajiban adalah 1 (satu) bulan sejak diterbitkan surat ketetapan pajak atau surat sejenis. Bila melewati jatuh tempo, maka negara diwakilkan jurusita dapat melaksanakan penagihan aktif untuk memaksa wajib pajak melunasi utang pajak.

Dalam Pasal 1 ayat (6) UUK-PKPU, kewajiban usaha perseroan pailit dibagi menjadi dua yaitu kewajiban yang timbul akibat perjanjian atau dari perikatan berdasarkan undangundang. Berdasarkan pengertian tersebut, utang pajak merupakan utang yang timbul karena perikatan undang-undang berbeda dengan utang niaga yang timbul akibat perjanjian perseroan dengan pihak lain. Perbedaan terjadi juga dalam penagihan utang niaga dilakukan berdasarkan hukum perdata, sedangkan utang pajak berdasarkan hukum publik (undang-undang perpajakan). Perbedaan lain terletak dalam pelunasan utang dimana utang niaga harus dilunasi 


\section{EDUCORETAX}

Volume 1 No. 1, Maret 2021

pihak perseroan, sedangkan utang pajak harus dilunasi oleh wajib pajak atau penanggung pajak perseroan.

\section{Kepailitan Perseroan Terbatas}

Menurut Bakti Siahaan (2008) pinjaman pada dasarnya merupakan hal yang wajar digunakan perseroan dalam mengembangkan usahanya, dengan syarat PT dapat membayar kembali pinjaman tepat pada waktunya. Berjalannya waktu jika perseroan terus mengalami kerugian hingga mengalami keadaan insolvent, maka pengelola PT dapat dianggap mengalami kelalaian. Terdapat dua faktor kelalaian perseroan yaitu faktor kesengajaan atau disebabkan keterpaksaan perseroan dalam mengelola keuangannya (Asikin,2001).

Dalam keadaan PT mengalami insolvent, para kreditur atau perseroan sendiri dapat mengajukan permohonan pailit atas perseroan. Syarat agar debitur dapat dinyatakan pailit tertuang pada Pasal 2 ayat (1) UUK-PKPU, yaitu:

a. Debitur mempunyai dua atau lebih kreditur;

b. Debitur tidak membayar lunas sedikitnya satu utang yang telah jatuh waktu dan dapat ditagih.

Pengertian kepailitan yang tertuang pada Pasal 1 angka 1 UUK-PKPU, memiliki pengertian pailit sebagai sita umum atas semua kekayaan debitur pailit yang pengurusan dan/atau pemberesannya dilakukan oleh kurator dibawah pengawasan Hakim Pengawas. Tujuan proses pailit yang dilakukan oleh Hakim Pengawas dan kurator selaku lembaga kepailitan, berguna untuk menjamin adanya keadilan bagi kreditur maupun debitur. Jaminan bahwa proses pailit debitur tidak akan berbuat curang dan bertanggung jawab atas semua utangutangnya. Pada sisi kreditur diberikan perlindungan atas hak yang harus didapat (Sastrawidjaja, 2006).

\section{METODE}

Pada penelitian ini, penulis menggunakan metode kualitatif. Pemilihan metode ini dilakukan untuk mendeskripsikan realitas tindakan penagihan terhadap wajib pajak badan PT pailit dan membandingkannya dengan peraturan perundang-undangan terkait. Penulis mengumpulkan data dan informasi melalui sumber tertulis dengan cara membaca dan mempelajari buku literatur terkait proses kepailitan. Selain buku penulis juga membaca dan mempelajari jurnal ilmiah maupun karya tulis ilmiah dengan menggunakan metode penelitian studi kasus dan norma yudisial. Penulis mengajukan permintaan data secara langsung ke KPP Wajib Pajak Besar Satu berkaitan dengan topik yang diangkat. Pengumpulan data dan informasi dalam metode ini dilakukan dengan cara wawancara dan observasi. Penulis melakukan wawancara langsung dengan narasumber yaitu Jurusita Pajak KPP Wajib Pajak Besar Satu berkaitan tindakan penagihan pajak atas wajib pajak badan PT pailit. Penulis mengumpulkan, mempelajari, dan mengolah data-data yang diperoleh serta memahami dokumen-dokumen dari hasil penelitian.

\section{HASIL DAN PEMBAHASAN}

\section{Proses Tindakan Penagihan Wajib Pajak Badan Pailit}

Tindakan Penagihan Pajak sebelum wajib pajak badan dalam proses dilakukan dengan menggunakan prosedur sesuai UU PPSP. Berdasarkan wawancara yang dilakukan bersama narasumber, dalam proses tindakan penagihan terdapat beberapa kasus dimana wajib pajak mengalami kepailitan. Proses pailit yang berjalan tidak menghentikan tindakan penagihan pajak, melainkan tindakan penagihan tetap berjalan dengan penyesuaian mengikuti proses kepailitan yang berlangsung.

Pemberitahuan wajib pajak pailit sangat penting karena terdapat jangka waktu verifikasi utang pajak yang akan dimasukan kurator dalam boedel pailit. Pemberitahuan disampaikan oleh 


\section{EDUCORETAX}

Volume 1 No. 1, Maret 2021

kurator yang dipilih Hakim Pengawas selaku penanggung jawab perusahaan pailit melalui surat ke KPP (Kantor Pelayanan Pajak) wajib pajak terdaftar, dan/ atau media massa skala nasional seperti surat kabar. Dalam hal wajib pajak badan yang pengurusnya juga dinyatakan pailit maka kurator akan membuat surat tembusan kepada KPP dimana pengurus terdaftar sebagai wajib pajak.

Pemberitahuan pailit yang dilakukan kurator biasanya disertakan permohonan daftar utang wajib pajak. Berdasarkan surat permohonan daftar utang tersebut, jurusita pajak akan melakukan konfirmasi utang pajak dalam SIDJP (Sistem Informasi Direktorat Jenderal Pajak) terkait ketetapan-ketetapan utang pajak wajib pajak pailit. Daftar utang pajak yang telah terkonfirmasi kemudian diserahkan kepada kurator.

Setelah kurator selesai mendata seluruh aset wajib pajak badan dan seluruh utang dari para kreditur, maka setiap kreditur akan dipanggil melakukan rapat verifikasi. Dalam hal kurator telah melakukan perhitungan pembagian aset pajak kepada setiap kreditur maka akan diberitahukan kepada setiap kreditur. Para kreditur yang merasa keberatan atas pembagian kurator dapat mengajukan keberatan ke pengadilan niaga, kemudian jika saat keberatan masih terdapat ketidakpuasan dapat mengajukan kasasi ke Mahkamah Agung, kemudian tindakan hukum terakhir merupakan peninjauan kembali. Selama proses berlangsung, kurator tidak dapat melakukan pembagian maupun mencabut pailit atas debitur pailit.

\section{Posisi Pajak dalam Proses Pailit}

Berdasarkan penjelasan Pasal 21 UU KUP menerangkan negara sebagai kreditur preferen memiliki hak mendahulu atas aset penanggung pajak dalam proses pailit. Dalam wawancara yang dilakukan penulis, terdapat fakta bahwa penjelasan negara sebagai kreditur preferen memberikan hambatan tersendiri posisi utang pajak dalam proses pailit. Pelaksanaan hak mandahulu pada proses pailit pada kenyataannya tidak memberikan dampak untuk didahulukan dalam proses pailit.

Hambatan yang terjadi mengenai posisi utang pajak dalam proses pailit. Dalam proses pailit bersinggungan dengan kepentingan banyak pihak kreditur yang memiliki kekuatan hukum kuat untuk didahulukan (lex specialis). Tidak adanya dasar hukum yang mengatur posisi kreditur dalam proses pailit memberikan dampak pada posisi utang pajak yang tidak dapat didahulukan.

Selain melunasi utang terhadap kreditur pailit, terdapat biaya kepailitan dan pemberesan harta pailit kepada kurator. Berdasarkan Pasal 18 UUK-PKPU biaya dan imbalan jasa kurator (biaya pailit) mendapat hak mendahulu atas semua utang yang tidak dijamin dengan agunan. Biaya pailit terjadi akibat adanya pemberesan tagihan pailit yang dilakukan oleh kurator yang dibayar melalui aset pailit. Pertimbanan tersebut membuat pailit didahulukan sebagai jaminan untuk kurator menyelesaikan pemberesan tagihan pailit. Penetapan biaya pailit tidak dapat diajukan upaya hukum. Perhitungan biaya pailit dilakukan dengan persentase pada setiap harta pailit kecuali harta agunan. Biaya pailit menjadi utang pailit yang harus dikeluarkan dari harta pailit.

Berdasarkan Putusan Mahkamah Konstitusi Nomor 67/PUU-XI/2013 yang mengubah Pasal 95 ayat (4) Undang-Undang Nomor 13 Tahun 2003 tentang Ketenagakerjaan, ditegaskan bahwa pembayaran upah pekerja/buruh didahulukan atas semua jenis kreditur. Termasuk atas tagihan kreditur separatis, tagihan hak negara, kantor lelang, dan badan umum yang dibentuk pemerintah, sedangkan pembayaran hak-hak pekerja/buruh lainnya didahulukan atas semua tagihan termasuk tagihan hak negara, kantor lelang, dan badan hukum yang dibentuk pemerintah, kecuali tagihan dari kreditur separatis. Dalam proses pailit upah pekerja/buruh akan didahulukan dalam prioritas pelunasan utang pajak oleh kurator. 


\section{EDUCORETAX}

Volume 1 No. 1, Maret 2021

Berdasarkan Pasal 1134 KUH Perdata hak istimewa merupakan suatu hak yang diberikan oleh undang-undang kepada seorang kreditur yang menyebabkan ia berkedudukan lebih tinggi daripada yang lainnya, semata-mata berdasarkan sifat piutang gadai dan hipotik lebih tinggi daripada hak istimewa, kecuali dalam hal undang-undang dengan tegas menyatakan kebalikannya.

Dalam Pasal 21 UU KUP walaupun ada penjelasan hak istimewa sebagai kreditur preferen, namun tidak ada penegasan atas utang apa pajak mendapat hak istimewa. Hal ini menyebabkan utang pajak yang memiliki posisi sebagai kreditur preferen dalam proses pailit pelunasannya di bawah kreditur separatis. Berdasarkan pembahasan yang telah dilakukan, diketahui posisi pelunasan utang dalam proses pailit sebagai berikut (1) Biaya dan imbalan jasa curator; (2) Upah pekerja atau buruh; (3) Kreditur separatis; (4) Kreditur Preferen (Pajak); dan (5) Kreditur Konkuren.

\section{Kendala Penagihan Wajib Pajak Pailit}

Dalam melaksanakan tindakan penagihan wajib pajak badan dalam proses pailit terdapat beberapa kendala yang dihadapi jurusita pajak KPP Wajib Pajak Besar Satu, antara lain yaitu:

- Kesulitan berkomunikasi dengan penanggung pajak

Kesulitan berkomunikasi terjadi ketika Penanggung Pajak atas wajib pajak badan pailit tidak dapat ditemui atau tidak diketahui keberadaannya. Dalih sedang dalam proses pailit menjadi alasan untuk menghindari tanggung jawab. Terutama bila pemilik merupakan Warga Negara Asing yang membuat terbatasnya komunikasi.

- Daluwarsa penagihan wajib pajak

Durasi proses pailit yang berjalan lama dan tidak terdapat kepastian penyelesaian pailit berbanding terbalik dengan jangka waktu penagihan yang sudah pasti yaitu 5 (lima) tahun. Hal ini membuat jurusita harus merancang strategi memaksimalkan tindakan penagihan sebelum daluwarsa penagihan.

- Pembatasan ruang gerak tindakan penagihan

Dimulainya proses pailit memang tindakan penagihan dapat dilaksanakan, namun proses tersebut juga membatasi gerak tindakan penagihan. Beberapa tindakan penagihan yang tidak terlaksana adalah penyitaan aset wajib pajak dan pemblokiran. Hal ini dikarenakan aset dalam status sita dan dikelola oleh kurator.

- Pandemi

Pada masa pandemi Covid-19 juga memberi dampak kepada proses penagihan. Pandemi secara tidak langsung memperlama proses penagihan karena tidak dapat berkoordinasi langsung. Termasuk dalam tidak menentunya jangka waktu pailit karena kurator harus mendata seluruh aset dan utang wajib pajak, juga kesulitan dalam menjual aset perusahaan karena daya beli masyarakat yang sedang turun pada masa pandemi.

- Kompleksitas peraturan

Alat utama penagihan dalam mengamankan penerimaan negara adalah peraturan. Adanya peraturan yang bias dan memberikan banyak persepsi tentu akan menyulitkan posisi jurusita pajak dalam mempertahankan penerimaan negara. Terlebih proses pailit merupakan proses yang bersinggungan dengan banyak peraturan perundang-undangan lain, dimana peraturan tersebut digunakan setiap pihak mempertahankan kepentingannya dalam menerima pembayaran utang.

- Masih terdapat utang pajak

Proses pailit tidak serta merta akan melunasi utang pajak. Dalam pembagiannya aset perusahaan pailit yang telah terjual akan dilakukan proporsi pembagian oleh kurator. 


\section{EDUCORETAX}

Volume 1 No. 1, Maret 2021

Bila aset perusahaan lebih kecil dari utang perusahaan, kemungkinan besar utang pajak tidak dapat lunas seluruhnya.

- Utang pajak sementara

Saat terjadi keberatan dilakukan oleh wajib pajak sebelum pailit, atas utang pajak tidak dapat sepenuhnya dimasukan dalam boedel pailit. Utang pajak yang belum dapat dimasukan dalam boedel pailit menjadi utang sementara. Harus terjadi keputusan yang inkrah atas utang pajak untuk dimasukan kedalam boedel pailit sehingga harus menunggu selesainya proses keberatan yang sedang berlangsung dan terbit keputusan yang inkrah atas utang pajak.

\section{Solusi yang telah diterapkan dalam menghadapi hambatan tindakan penagihan terhadap wajib pajak badan pailit}

Dalam menghimpun informasi, terdapat beberapa langkah strategis yang dapat diambil dalam melakukan tindakan penagihan terhadap wajib pajak pailit sebagai berikut:

a. Kendala Daluwarsa Tindakan Penagihan

Pada saat jurusita pajak mendapat informasi wajib pajak pailit maka lebih baik mengukur sisa daluwarsa penagihan wajib pajak dan menelusuri kembali tindakan penagihan sebelum wajib pajak dalam proses pailit. Bila belum dilakukan penerbitan Surat Paksa maka lebih baik menunda penerbitan Surat Paksa. Namun jika ternyata telah diterbitkan Surat Paksa tindakan yang dapat dilakukan adalah melakukan tindakan persuasif kepada wajib pajak untuk mendapatkan pengakuan utang pajak dari wajib pajak baik langsung maupun tidak langsung. Pengakuan utang pajak hanya dapat dilakukan bila wajib pajak kooperatif dan dapat ditemukan. Tindakan ini berdasarkan Pasal 22 ayat (2) UU KUP, dimana penerbitan Surat Paksa dan pengakuan utang pajak dari wajib pajak dapat menyebabkan tertangguhnya daluwarsa penagihan pajak.

b. Terdapat sisa utang pajak tidak dapat ditagih setelah proses pailit

Hambatan lain saat terdapat sisa utang pajak tidak dapat ditagih setelah proses pailit. Sering terjadi mengingat posisi utang pajak sering berada di belakang hak buruh dan kreditur separatis. Berdasarkan Pasal 32 ayat (2) UU KUP solusi hambatan ini dengan melakukan tindakan penagihan diteruskan ke penanggung pajak. Pada saat wajib pajak dalam proses pailit memang tanggung jawab akan beralih kepada kurator sebagai debitur pailit. Namun saat pembagian utang debitur pailit telah selesai kemudian kepailitan wajib pajak dicabut maka penanggung pajak kembali ke wakil wajib pajak badan sebelum terjadinya pailit. Suatu perusahaan dinyatakan pailit tidak menjadikan perusahaan tersebut bubar dan utang pajak hilang. Kepengurusan bubar ketika setelah pailit perusahaan melakukan likuidasi dan pembubaran.

Sebagaimana pengertian PT bahwa harta terpisah dari penanggung pajaknya, sehingga dapat diketahui bahwa harta penanggung pajak saat pailit tidak termasuk harta yang dilakukan sita umum oleh kurator. Atas dasar tersebut tindakan penagihan wajib pajak badan pailit dapat beralih kepada tindakan penagihan kepada penanggung pajak dengan perkiraan penanggung pajak wajib pajak badan pailit masih memiliki harta untuk melunasi utang pajak. Berdasarkan penilaian atas fakta dan hukum yang dilakukan selama proses Uji Materiil Pasal 2 ayat (6) dan Pasal 32 ayat (2) UU KUP, Mahkamah Konstitusi memutuskan menolak pemohon untuk seluruhnya. Putusan ini tertuang dalam Putusan Mahkamah Konstitusi Nomor 41/PUU-XVIII/2020. Atas putusan tersebut, semakin menguatkan tindakan penagihan pajak dalam mengatasi kendala posisi utang pajak yang tidak menentu pada proses pailit. Pada masa yang akan datang, tindakan penagihan pajak tetap dapat berjalan dengan kepastian hukum untuk menagih penanggung pajak. Hal ini berdampak pada pengamanan penerimaan negara. 


\section{EDUCORETAX}

Volume 1 No. 1, Maret 2021

\section{PENUTUP}

Tindakan penagihan aktif terhadap wajib pajak badan PT dalam proses pailit tidak dapat dilakukan sebagai bentuk menghormati proses hukum pailit. Pelunasan utang pajak dilakukan oleh kurator. Setelah proses pailit selesai dan terdapat sisa utang pajak, tindakan penagihan dapat diteruskan kepada penanggung pajak.

Berdasarkan pembahasan yang dilakukan dapat disimpulkan posisi kreditur dalam proses pailit yang pertama merupakan biaya dan imbalan jasa kurator (Pasal 18 UUK-PKPU), kedua upah pekerja atau buruh (Putusan Mahkamah Konstitusi Nomor 67/PUU-XI/2013), ketiga kreditur separatis (Pasal 1134 KUH Perdata), keempat utang pajak sebagai kreditur preferen (Pasal 21 UU KUP), dan yang kelima adalah kreditur konkuren.

Jurusita KPP Wajib Pajak Besar Satu dalam melaksanakan tindakan penagihan terhadap wajib pajak dalam proses pailit mengalami kendala-kendala yang dihadapi, antara lain penanggung pajak wajib pajak PT sulit ditemui, daluwarsa tindakan penagihan, pembatasan ruang gerak tindakan penagihan, pandemic, kompleksitas peraturan, terdapat sisa utang pajak setelah proses selesai, dan utang pajak sementara.

Beberapa kendala tindakan penagihan terhadap wajib pajak badan pailit yang dapat diatasi dengan langkah strategis. Kendala pertama merupakan kendala daluwarsa tindakan penagihan yang dapat diatasi dengan pengaturan penerbitan Surat Paksa atau pendekatan secara persuasif dengan penanggung pajak. Kemudian kendala utang pajak yang masih tersisa setelah proses pailit selesai yang dapat dilakukan tindakan penagihan terhadap penanggung pajak wajib pajak badan.

\section{DAFTAR PUSTAKA}

Asikin, Zainal. (2001). Hukum Kepailitan \& Penundaan Pembayaran di Indonesia. Jakarta: Rajawali Press.

Fernandez. (2012). Tinjauan Yuridis Hak Mendahulu Pelunasan Utang Pajak Atas Harta Pailit dan Penyelesaian Utang Pajak Dalam Kepailitan. Skripsi Universitas Indonesia.

Irawan, Bagus. (2007). Aspek-Aspek Hukum Kepailitan; Perusahaan; dan Asuransi. Bandung: PT. Alumni.

Khairandy, Ridwan. (2009). Perseroan Terbatas, Doktrin, Peraturan Perundang-undangan dan Yurisprudensi. Yogyakarta: Kreasi Total Media.

Sastrawidjaja, Man S. (2006). Hukum Kepailitan dan Penundaan Kewajiban Pembayaran Utang. Bandung: PT. Alumni.

Siahaan, Bakti. (2008). Akibat Hukum Pernyataan Kepailitan Perseroan Terbatas. Jurnal Universitas Syiah Kuala,Banda Aceh.

Siburian, Ruth Yohana. Susilowati, Etty. dan Ispriyarso, Budi. (2017). Tanggung Jawab Kurator Terhadap Pemenuhan Hak Negara Atas Utang Pajak Perseroan Terbatas Pada Kepailitan. Diponegoro Law Journal, 6 (1), 2-6.

Suharyanto, Anton. (2013). Implementasi Undang-Undang Kepailitan dan Implikasinya terhadap Piutang Negara. Jakarta: BPPK Departemen Keuangan.

Susilowati, Etty. (2011). Hukum Kepailitan dan Penundaan Kewajiban Pembayaran Utang. Semarang: Badan Penerbit Universitas Diponegoro.

Soemitro, Rochmat. (1990). Asas dan Dasar Perpajakan. Bandung: PT. Eresco. 


\section{EDUCORETAX}

Volume 1 No. 1, Maret 2021

Teguh, Rahmad. (2016). Kewajiban Perseroan Terbatas yang Dinyatakan Pailit Terhadap Utang Pajak yang Belum Dibayar (Studi Kasus Putusan Mahkamah Agung No. 406/K/Pdt.SusPailit/2015). Skripsi Universitas Narotama Surabaya.

Kitab Undang-Undang Hukum Perdata [Burgerlijk Wetboek], diterjemahkan oleh R. Subekti, R Tjitrosudibio. Jakarta: Balai Pustaka, 2014.

Peraturan Menteri Keuangan Nomor 189/PMK.03/2020 tentang Tata Cara Pelaksanaan Penagihan Pajak atas Jumlah Pajak yang Masih Harus Dibayar. Jakarta: Sekretariat Negara.

Putusan Mahkamah Konstitusi Nomor 41/PUU-XVIII/2020 perihal Pengujian Undang-Undang Nomor 6 Tahun 1983 tentang Ketentuan Umum dan Tata Cara Perpajakan sebagaimana diubah dengan Undang-Undang Nomor 28 Tahun 2007 tentang Perubahan Ketiga Atas Undang-Undang Nomor 6 Tahun 1983 tentang Ketentuan Umum dan Tata Cara Perpajakan terhadap Undang-undang Dasar Negara Republik Indonesia Tahun 1945.

Surat Edaran Direktur Jenderal Pajak Nomor 07/PJ/2020 tentang Kebijakan Pengawasan dan Pemeriksaan Wajib Pajak Dalam Rangka Perluasan Basis Pajak. Jakarta: Direktorat Jenderal Pajak.

Undang-Undang Republik Indonesia Nomor 19 tahun 2000 perubahan atas Undang-Undang 19 tahun 1997 tentang Perubahan Atas Undang-Undang Nomor 19 tahun 1997 Tentang Penagihan Pajak Dengan Surat Paksa. Jakarta: Sekretariat Negara.

Undang-Undang Republik Indonesia Nomor 28 tahun 2007 tentang Perubahan Ketiga Atas Undang-Undang Nomor 6 Tahun 1983 tentang Ketentuan Umum dan Tata Cara Perpajakan. Jakarta: Sekretariat Negara.

Undang-Undang Republik Indonesia Nomor 37 Tahun 2004 tentang Kepailitan dan Penundaan Kewajiban Pembayaran Utang. Jakarta: Sekretariat Negara.

Undang-Undang Republik Indonesia Nomor 40 Tahun 2007 tentang Perseroan Terbatas. Jakarta: Sekretariat Negara.

Undang-Undang Republik Indonesia Nomor 13 Tahun 2003 tentang Ketenagakerjaan. Jakarta: Sekretariat Negara. 